\title{
The Most Important Particle (Ta najważniejsza cząsteczka)
}

\author{
Author: Stanisław Benski
}

First Published: 1982

Translation: English (Colored Drawings, Missing Pieces, Snapshots and The Tzaddik's Grandson in Missing Pieces, 1990).

About the Author: Stanisław Benski (1922-1988) was a Polish writer of Jewish origin. In 1939-1943, he lived in the Soviet Union, and later, in 1943-1946, he served in the Polish People's Army (Ludowe Wojsko Polskie). After World War II he studied law at the University of Warsaw. He worked for many years as director of the State Social Welfare Home for the Aged.

Further Important Publications: Zwiadowcy (1965, Rangers; short stories); Tyle ognia wokoło (So Much Fire Around, 1979; short stories); Jeden dzień (One Day, 1980; novel); Cesarski walc (Caesarean Waltz, 1985; short stories); Ocaleni (Survivors, 1986; novel); Strażnik świąt (A Guard of the Feast, 1987; short stories).

\section{Content and Interpretation}

The Most Important Particle, like other works by Benski, focuses on Holocaust survivors whose lives in postwar Warsaw consist of an everyday and often unbearable struggle to regain their lost identity. The cast of characters includes a group of Polish Jews who managed to survive or escape the ghettos and camps, although they remain prisoners of a past burdened with many traumatic experiences.

The collection consists of thirteen stories, each one narrating a deceptively ordinary incident involving the sick and mostly elderly residents of the Welfare Home for Holocaust Survivors ( $\rightarrow$ The Boarding House, $\rightarrow$ Dr. Josef's Beauty). Those incidents and events, however, provide a pretext for returning to life before the war, before the Nazi occupation and resulting trauma, typically involving the loss of family members and other loved ones. This last theme can be found in all thirteen stories, but is most striking in The Tzaddik's Great-Grandson (Prawnuczek cadyka) where it appears in a discussion between one of the residents named Fajwel and guests from America who are descendants of Polish-Jewish immigrants. They have come to Poland to visit the tomb of their ancestor, a tzadik (or "holy man"), in order to pray for his great-grandson's recovery. Their visit to the Welfare Home is similarly motivated, as they expect to meet a man named Chaim who is considered to be a contemporary saint or tzadik and remains a symbol of lost heritage for the rest of the residents. The discussion that follows the arrival of the guests revolves around the figure of the God-fearing Jew and a notion of identity for American Jews that is defined by faith. In response to this topic, an irate Fajwel exclaims that there is no God, adding later that if God existed he

Ә Open Access. ( 2021 Anna Maria Skibska, published by De Gruyter. (c))BY-NC-ND This work is licensed under a Creative Commons Attribution-NonCommercial-NoDerivatives 4.0 License. https://doi.org/10.1515/9783110671056-070 
would have saved his wife and son from the ghetto. The guests cannot understand Fajwel's attitude, highlighting the futility of putting one's experiences into words.

The titular The Most Important Particle (translated elsewhere as "Missing Pieces") raises an especially important issue, presenting the tragicomic story of a Polish-Jewish couple that did not directly experience the war, the German occupation, or the Holocaust. Gabriel Lewin, along with members of his immediate family, spent the period in question at his brother's home in New York, while his wife Róża spent it in Uzbekistan. After meeting again in postwar Poland, the two got married. In contrast to the victims and survivors of mass extermination, the Lewins are in a special situation that they find increasingly uncomfortable, one that sets them radically apart from most other European Jews. This difference gradually becomes a burden for them, which they decide to cope with by creating their own fictional wartime biographies, drawing on facts and events typical of the Polish-Jewish wartime experience: the bombardment of 1939, the resistance, life in occupied Warsaw (not in the ghetto, but on the Aryan side), and so on. The sham lives they write in this way, both grotesque and immoral, rooted in a deep need for being full members of their home community, but also prove a tragic lack of identification with other people of Jewish origin. Nevertheless, the effort helps them recall their friend Janeczka, whose individual tragedy consists in having no information about her early childhood. Knowing neither her mother nor her father, she roamed the streets of the occupied capital among strangers and in shelters, and in this way managed to survive. Now, absorbed in the quest for her own beginnings, Janeczka walks the streets of Warsaw in search of resolution and "the first and most important particle" of her life.

\section{Main Topics and Problems}

Focused on the lives of Holocaust survivors, Benski presents their dramatic fight for lost identity, a fight in which many characters sustain themselves on a form of memory that spans two different temporal streams: one characterised by a prewar Arcadia, the other the dark times of war. The survivor's memory is necessarily in conflict with itself, presenting the characters, on the one hand, with a way to mentally reconstruct the years before the war (its therapeutic function), and on the other, with destabilising mental shocks as the recourse to memory brings back former traumas. With Benski, the destructive force of war and the Great History returns endlessly to his characters' personal histories, so that it becomes the most important topic of the survivors' daily conversations.

Benski's style oscillates between a traditional realism reminiscent of the nineteenth-century novel, which serves as a medium for his literary portraits and depictions, and a parable poetics that enhances the overtones of his short stories. He also makes use of the aesthetics of farce, which allows him to avoid excessive pathos. By using the resources of a "transparent language", Benski is able to render his existential metaphors with evident clarity. The author concentrates on the theme of orphaned and disappearing communities, juxtaposed with well-developed character relations. 
He places special emphasises, moreover, on those relations characterised by selfless care, friendship, respect, etc. While far from idealising his characters (their frailty, defects, addictions), Benski uncovers the real value of their common activities, interests, and conversations.

\section{Cited Work}

Benski, S. (1982). Ta najważniejsza cząsteczka. Warszawa: Czytelnik.

\section{Further References}

Shapira, A. (1998). The Holocaust: Private Memories, Public Memory. Jewish Social Studies, 4(2), pp. 40-58. Black, J. (2016). The Holocaust: History and Memory. Bloomington: Indiana University Press.

AMS 